\title{
The effect of ultrasound pretreatment on some selected physicochemical properties of black cumin (Nigella Sativa)
}

\author{
Masoumeh Moghimi ${ }^{*+}$, Vahid Farzaneh ${ }^{2 \dagger}$ (ID and Hamid Bakhshabadi ${ }^{3}$
}

\begin{abstract}
Background: In the present study, the effects of ultrasound pretreatment parameters including irradiation time and power on the quantity of the extracted phenolic compounds quantity as well as on some selected physicochemical properties of the extracted oils including oil extraction efficiency, acidity and peroxide values, color, and refractive index of the extracted oil of black cumin seeds with the use of cold press have been studied.

Methods: For each parameter, three different levels (30, 60, and $90 \mathrm{~W})$ for the ultrasound power and $(30,45$, and $60 \mathrm{~min}$ ) and for the ultrasound irradiation time were studied. Each experiment was performed in three replications.

Results: The achieved results revealed that, with enhancements in the applied ultrasound power, the oil extraction efficiency, acidity value, total phenolic content, peroxide value, and color parameters increased significantly $(P<0$. 01). Enhancements in ultrasound irradiation time have not significantly increased the oil extraction efficiency, acidity value, total phenolic content, and peroxide value as well as the oil refractive index $(P<0.05)$. As the highest oil extraction efficiency (39.93\%) was obtained from the seeds when the applied ultrasound power and time were 90 W and 60 min respectively, and the lowest acidity value of oil was achieved once the applied power and time of ultrasound were $30 \mathrm{~W}$ and 30 min respectively. The application of ultrasound as pretreatment has not shown any significant effects on the refractive index of the extracted oils $(P>0.05)$.
\end{abstract}

Conclusions: In summary, it could be mentioned that the application of ultrasound pretreatment in the oil extraction might improve the oil extraction efficiency, the extracted oil's quality, and the extracted phenolic compounds content.

Keywords: Ultrasound pretreatment, Black cumin, Total phenols, Physicochemical properties

\section{Background}

The oils and fats not only from their potential health benefits point of view, but also from commercial point of views have attracted considerable attention of researches. These compounds might provide considerable quantities of required energy of body cells, required essential fatty acids, as well as fat-soluble vitamins [1].

Recently, with a growth and increase of general knowledge in this area, the demand of people for application of oils increased due to different reasons including their potential health benefits and providing desirable taste

\footnotetext{
* Correspondence: moghimi_m52@yahoo.com

${ }^{\dagger}$ Masoumeh Moghimi and Vahid Farzaneh contributed equally to this work. ${ }^{1}$ Department of Chemistry, Gonbad Kavoos Branch, Islamic Azad University, Gonbad Kavoos, Iran

Full list of author information is available at the end of the article
}

and high energy quantities. Regarding the fact that Iran needs to import oilseeds from other countries in producing vegetable oil or in other words rather than $90 \%$ of the consumed oil in Iran is provided from foreign countries, therefore the application of available oil sources in Iran for achieving self-healing and enhancement of the cultivated area under common oilseeds and exploration as well as cultivating novel oil sources are steps toward providing the required oil sources in countries suffering from lack of appropriate edible oil sources. Oils and fats prepared from various plant species and animal sources may have different metabolic, physical, and chemical properties regarding their species [2]. Nigella sativa (black cumin) seeds, a dicotyledon of Ranunculaceae family, have been used since thousands of years ago as a

(c) The Author(s). 2018 Open Access This article is distributed under the terms of the Creative Commons Attribution 4.0 International License (http://creativecommons.org/licenses/by/4.0/), which permits unrestricted use, distribution, and 
spice and food preservative [3-5]. Thymoquinone, the main ingredient of the essential oil of $N$. sativa seeds, was also capable to reveal beneficial effects on acute gastric ulcer [6]. In addition, thymoquinone and its reduced product named thymohydroquinone have been reported to have antibacterial activities and might be associated with some further antibiotic activities [7]. The moisture, protein, and carbohydrate as well as oil contents of oilseeds are generally found in the range of $0.52-7.43 \%$, $20-27 \%, 23.5-33.2 \%$, and $25-32 \%$ respectively [8]. Black cumin seeds contain tocopherol contents including $\alpha, \beta$, and $\gamma$ types. Among them, sterols and beta-cytosterols are the most important and predominant compounds in the extracted oil of black cumin seeds followed by Stigma sterols demonstrating 18.6 and 69\% quantities respectively. Different approaches might be used to extract oil from oil seeds such as solvent extraction including Soxhlet and mechanical methods [9]. Oil extraction with the use of mechanical approach is simple, safer, and less expensive compared to oil extraction with solvent and it has more advantages [10].

Recently, green extraction technologies including microwave, ultrasound, pulse electric field, instant controlled pressure drop, supercritical fluid processing in the frontiers of food processing, food chemistry, and food microbiology are not considered as novel approaches and have been used for rather than 30 years by academia and in different industries under extreme or non-classical conditions (currently a dynamically developing area in applied research and industry). Alternatives to conventional processing, preservation, and extraction procedures may increase the production efficiency and contribute to environmental preservation by reducing the use of water and solvents, elimination of wastewater, fossil energy, and generation of hazardous substances. Within those constraints, green food processing has to be introduced on the basis of green chemistry and green engineering: green food processing is based on the discovery and design of different technical processes reducing energy and water consumption, allows recycling of by-products through bio-refinery, and ensures a safe and high-quality product [11]. It is almost a decade that novel extraction approaches have attracted considerable attention. In the abovementioned approaches, it has been tried to extract the oil in a most effective way to reduce the consumed solvent, time, and temperature and increase oil extraction efficiency and to reduce process expenses [9]. For instance, with the use of a combined method in extraction of functional compounds of pomegranate fruit, the tough and wooden parts of the fruit must be digested and decomposed with the assistance of further methods.

Application of novel approaches including microwave and pulsed electric field in most of cases might increase the oil extraction rate and efficiency [12]. Ultrasound is a novel technology used frequently in nutrition science $[13,14]$. Ultrasound is described as waves irradiated in the waves in the range of $18-20 \mathrm{kHz}$. When ultrasound wave is applied in liquid or semi-liquid products, acoustic pressure as well as hydrostatic pressure are created.

In an unlimited level, acoustic pressure normally is considered as a sinusoidal wave and depends on the frequency, time, and maximum wave length [15]. Oil extraction with ultrasound assistance is going to be considered as a replacement of traditional approaches in oil extraction industry due to having high extraction efficiency, less energy, and solvent consumption; moreover, it is considered as an improved approach in plant-based products particularly in extraction of compounds with lower molecular weight [16]. The positive role of ultrasound waves in extraction might be relevant to its effects on destruction of cells' membrane and as a result its impacts on extraction environment [17]. Ultrasound application includes processes that could enhance the rate of extraction, quality of the extracted oil, safety of the process, and reduce time of extraction [18].

Ultrasound advantages are associated to cavitation process. Small produced bubbles in liquid phase might grow when the product is exposed to ultrasound waves and might fluctuate due to pressure alterations before the bubbles' elimination [19].

The effective parameters on cavitations are frequency, liquid viscosity, solvent vapor pressure, external pressure, temperature, and available gas. Ultrasound frequency is one of the most effective factors in the size of the created bubbles. The effective parameters on cavitations are frequency, liquid viscosity, solvent vapor pressure, external pressure, temperature, and available gas. Ultrasound frequency is one of the most effective factors in the size of the created bubbles. The creation of cavitation needs high surface tension between gas and liquids; therefore, in liquids with low surface tension, less cavitation is created. Moreover, the trapped gas bubbles may facilitate the original cores of cavitation [11]. The triggering of materials from substrates may reach the cavitation bubble near the surface and then through compression cycles, bubble collapse happens. Slow flow of liquid with high rate is sucked to the surface of the particles and therefore in high pressure and temperature destructs the plant cellular septum and triggers the products [20].

An increasing number of companies already used the different ultrasonic technology, either by adapting their conventional or innovative systems of extraction or by alterations in their installation. In industrial scale, the majority of extracted compounds are directly used, as in liquor/or wine as well as beer production or can be used as food and cosmetic additives, in the case of essential 
oil and bioactive molecules. Euphytos and Giotto companies are Italian companies specialized in natural extracts from herbs, fruits, and vegetables with the use of ultrasound technology to improve the flavor and quality of the obtained extracts [11]. Zhang et al. [21], Lin et al. [22], and Goula [23] reported that the oil extraction efficiency with the use of ultrasound pretreatment might show enhancements. In the present study, the properties of the extracted oil of black cumin seeds with the use of ultrasound pretreatment have been studied and reported.

\section{Methods}

\section{Material}

The black cumin seeds used in the current research were provided from the animal feed stores of Gonbad-e-Kavoos at spring 2017, then they were transferred to Azad University of Gonbad-e-Kavoos for oil extraction process. The chemical materials used in the present research including sodium hydroxide, phenolphthalein, sodium carbonate, glycolic acid, folic acid, Folin-Ciocalteu reagent (FCR), sodium thiosulfate, potassium iodide, and ethyl alcohol were provided from Merck Company (Germany) and all of the chemicals and reagents were provided from analytical grade.

\section{Sample preparation and the pretreatments applied conditions before the oil extraction process}

In the present research, the black cumin seeds (containing $41.8 \%$ oil content) were prepared; after moving to the lab, they were sieved and kept in plastic bags which were resistant to air and moisture penetration until the experimental day. Then, $500 \mathrm{~g}$ of sample for each treatment was shifted in a 1.5-1 container that has been located inside the ultrasonic bath. Afterward, they were affected by the different conditions of ultrasound pretreatments (30, 60, and $90 \mathrm{~W}$ ) with the constant frequency equal to $25 \mathrm{kHz}$, and ultrasound irradiation time (30, 45, and $60 \mathrm{~min})$. After the pretreatments were completed, the oilseeds were extracted with the use of a screw press with $33 \mathrm{rpm}$, and the selected experiments were performed.

\section{The oil extraction efficiency}

To determine the oil extraction efficiency first, the weight of the used sample (oilseeds) and the extracted oil were detected, then the extraction efficiency was calculated and detected with the use of the Eq. 1 reported by [24].

$$
\begin{aligned}
& \text { Oil extraction efficiency }(\%) \\
& =\frac{\text { the weight of the extracted oil }}{\text { the weight of the initial seeds }} \times 100
\end{aligned}
$$

\section{Acidity value determination}

To determine the acidity value, the reported approach of AOCS 3-63, 1993 [25] was applied. Firstly, $5 \mathrm{~g}$ of the extracted oil was mixed with $20-30 \mathrm{~mL}$ ethanol and/or other neutralized alcohol and titrated with the addition of $0.1 \mathrm{~N} \mathrm{NaOH}$ in the presence of phenolphthalein as an indicator; finally, the acidity value was determined with the use of the following Eq. (2):

$$
A=\frac{282 \times N \times V}{1000 \times W} \times 100
$$

where $N$ indicates the normality of sodium hydroxide $(\mathrm{NaOH}), V$ presents the volume of the consumed $\mathrm{NaOH}$, $W$ represents the weight of the sample (g), and $A$ expresses the fatty acids content based on oleic acid in $100 \mathrm{~g}^{-1}$ sample.

\section{Determination of the refractive index}

The refractive index value of the extracted oil was detected with the use of a refractometer device in the temperature equals to $25{ }^{\circ} \mathrm{C}$ according to the released approach by (AOCS Cc 7-25).

\section{Color index measurement}

For color analysis, a spectrophotometer and AOCS Cc 13-92 approach (1993) were applied. In this regard, the optical density of the extracted oil was detected at 460 , 550,620 , and $670 \mathrm{~nm}$ wavelengths with the use of spectrophotometric approach and through Eq. 3 according to the released Lovibond yellow color.

$$
\begin{aligned}
\text { Color index }= & 1.29 \text { A } 460+69.7 \text { A550 } \\
& +41.2 \text { A620-56.4 A670 }
\end{aligned}
$$

\section{Determination of the peroxide index}

The peroxide value of the extracted oil was detected according to the AOCS Cd 8-53 method (1993). Five grams of oil was weighted in a 250-mL Erlenmeyer flask followed by adding $300 \mathrm{~mL}$ acetic acid-chloroform solvent with a ratio of 3:2; after stirring vigorously and mixing of the obtained solution, $0.5 \mathrm{~mL}$ of saturated potassium iodide solution was added, then the container containing the mixed solution was stand in darkness for $1 \mathrm{~min}$. Afterward, $30 \mathrm{~mL}$ of distilled water was added and titrated with the use of $0.1 \mathrm{M}$ sodium thiosulfate, and the titration was continued until the yellow color was disappeared. Finally, $0.5 \mathrm{~mL}$ of starch indicator reagent was added and the titration was continued until the blue color was disappeared and the peroxide value was detected and calculated through the following equation (Eq. 4):

$$
\mathrm{PO}=\frac{S \times M \times 100}{W .}
$$

where $S$ indicates the volume of the consumed sodium thiosulfate solution in milliliters, $M$ expresses sodium thiosulfate molarity, $W$ presents weight of the extracted 
oil in grams, and $\mathrm{PO}$ is the oil peroxide value in $\mathrm{mEq}$ of oxygen per $\mathrm{kg}^{-1}$ of the extracted oil.

\section{Total phenolic compounds content}

The total phenolic compounds have been determined through colorimetric method with the use of Folin-Ciocalteu's phenol reagent. In this regard, $0.5 \mathrm{~mL}$ of sample was diluted up to $5 \mathrm{~mL}$ with distilled water. Then, $0.5 \mathrm{~mL}$ of Folin-Ciocalteu's reagent was added to the diluted sample. After $3 \mathrm{~min}, 0.5 \mathrm{~mL}$ of $10 \%$ sodium carbonate was added to the abovementioned solution and was stand in room temperature at darkness for an hour. Finally, the samples' absorption was recorded at room temperature with the use of a UV spectrophotometer at wavelength of $760 \mathrm{~nm}$. Gallic acid was used to draw a standard curve ( 0 to $1000 \mu \mathrm{g}$ in $\mathrm{mL}$ ) and the total phenolic compounds content was calculated and the achieved data were reported as mg Gallic acid equivalent per each $\mathrm{kg}$ of sample.

\section{Statistical analysis}

The data analysis was performed using a completely random design in the form of $3 \times 3$ factorial experiments with three levels of irradiation power and three levels of irradiation time, each one in three different replications. The SAS software was used to analyze the information and Duncan's multiple range test was used to compare the data mean.

\section{Results and discussions}

\section{The oil extraction efficiency}

The obtained results demonstrated that with enhancements in ultrasound power and irradiation time, the oil extraction efficiency increased. With enhancements in applied pretreatments power, the oil extraction efficiency showed $30.81 \%$ boosting (Table 1), and with an increase in irradiation time, the oil extraction efficiency was enhanced up to $10.35 \%$ (Table 2).

The achieved results demonstrated that in ultrasound pretreatment, the power of the applied wave has affected the oil extraction efficiency rather than irradiation time. The taken images of scanning electron microscopy (SEM) (Fig. 1) confirmed that with application of ultrasound waves, due to decomposition of cells' membrane and enhancements of holes numbers, the quantity of the extracted oil will increase.
The ultrasound effect depends on the alterations in the environment, in other words, when cavitation bubbles implode in a solid surface, a distortion in the pressure zone occurs and increases up to $400 \mathrm{~km} \mathrm{~h}^{-1}$. This high rate implosion leads to the removal and rupture of cell membranes or increases their porosity, facilitating the mass transfer from the cells' interior [26, 27]. Cavitation speed, sequential contraction, and expansions depend on the ultrasound frequency and cause deformations and create micro-channels [28]; as a result, it reduces the thickness of the boundary layer [29]. The controlling mechanism in high-power ultrasound extraction is also attributed to the mechanical alterations, cavitations, and thermal effects.

Similar results have also been detected in the studies of ultrasound-assisted extraction of oil from flaxseeds [21], tea seeds, and saikosaponins from radix bupleuri [30]. Zhang et al. [21] and Zhao et al. [30] found out that the oil yield increased with enhancements in the ultrasonic time and stayed constant when the ultrasound pretreatment was extended. Consequently, based on the achieved results, $30 \mathrm{~min}$ was selected as the optimized ultrasonic irradiation time. The obtained outcomes also presented that the maximized extraction efficiency was reached once the ultrasonic power and irradiation time were at the maximum value $(90 \mathrm{~W}$ and 60 min respectively) (Table 3). Ultrasound-assisted extraction has been applied in further industries such as Marine industry, and the achieved results demonstrated that with an enhancement in irradiation time, extraction efficiency increased. The maximum extraction efficiency was achieved $7.2 \%$ when the irradiation time was $60 \mathrm{~min}$, while in normal extraction in the same extraction time, the extraction efficiency achieved was 4.2\%. Enhancements in ultrasound irradiation time increases the cavitation period through oil extraction and as a result boosts oil extraction efficiency [31].

Different microscopic observations (SEM, environmental scanning electron microscopy (e-SEM), cyto-histochemistry) have been used for spacial and temporal localization of metabolites in rosemary leaves, that is one of the most studied and important plant species due to containing antioxidant metabolites used frequently in different food industries, during conventional and ultrasound extraction. The study permits to highlight that ultrasound-impacted rosemary leaves not by a

Table 1 The influence of ultrasound power on some selected properties of samples

\begin{tabular}{lllllll}
\hline $\begin{array}{l}\text { Ultrasound } \\
\text { power }(\mathrm{W})\end{array}$ & $\begin{array}{l}\text { Oil extraction } \\
\text { efficiency (\%) }\end{array}$ & $\begin{array}{l}\text { Acidity } \\
\text { (oleic acid\%) }\end{array}$ & $\begin{array}{l}\text { Refractive } \\
\text { index }\end{array}$ & $\begin{array}{l}\text { Color } \\
\text { index }\end{array}$ & $\begin{array}{l}\text { Peroxide } \\
\text { (meq oxygen on kg oil) }\end{array}$ & $\begin{array}{l}\text { Total phenolic } \\
\text { content (ppm) }\end{array}$ \\
\hline 30 & $29.13 \mathrm{c}$ & $10.21 \mathrm{c}$ & $1.471 \mathrm{a}$ & $117.81 \mathrm{c}$ & $10.07 \mathrm{c}$ & $93.21 \mathrm{c}$ \\
60 & $35.01 \mathrm{~b}$ & $10.68 \mathrm{~b}$ & $1.471 \mathrm{a}$ & $120.60 \mathrm{~b}$ & $11.00 \mathrm{~b}$ & $99.80 \mathrm{~b}$ \\
90 & $37.98 \mathrm{a}$ & $12.09 \mathrm{a}$ & $1.471 \mathrm{a}$ & $126.10 \mathrm{a}$ & $12.00 \mathrm{a}$ & $106.60 \mathrm{a}$ \\
\hline
\end{tabular}

Data with different letters in each column indicate the significant differences in the confidence level of $5 \%$ 
Table 2 The influence of ultrasound irradiation time on some properties of samples

\begin{tabular}{lllllll}
\hline $\begin{array}{l}\text { Ultrasound } \\
\text { time }(\mathrm{min})\end{array}$ & $\begin{array}{l}\text { Oil extraction } \\
\text { efficiency (\%) }\end{array}$ & $\begin{array}{l}\text { Acidity } \\
\text { (oleic acid\%) }\end{array}$ & $\begin{array}{l}\text { Refractive } \\
\text { index }\end{array}$ & $\begin{array}{l}\text { Color } \\
\text { index }\end{array}$ & $\begin{array}{l}\text { Peroxide } \\
\text { (meq oxygen on kg oil) }\end{array}$ & $\begin{array}{l}\text { Total phenolic } \\
\text { content (ppm) }\end{array}$ \\
\hline 30 & $32.74 \mathrm{c}$ & $10.50 \mathrm{c}$ & $1.471 \mathrm{a}$ & $112.4 \mathrm{c}$ & $8.67 \mathrm{c}$ & $79.90 \mathrm{c}$ \\
45 & $33.25 \mathrm{~b}$ & $10.88 \mathrm{~b}$ & $1.471 \mathrm{a}$ & $118.80 \mathrm{~b}$ & $11.00 \mathrm{~b}$ & $101.72 \mathrm{~b}$ \\
60 & $36.13 \mathrm{a}$ & $11.59 \mathrm{a}$ & $1.471 \mathrm{a}$ & $133.30 \mathrm{a}$ & $13.40 \mathrm{a}$ & $118.00 \mathrm{a}$ \\
\hline
\end{tabular}

Data with different letters in each column indicate the significant differences in the confidence level of $5 \%$

single or different mechanisms in function of ultrasound power, as described by previous studies, but by a chain detexturation mechanism in a special order: local erosion, shear forces, sonoporation, fragmentation, capillary effect, and detexturation. These detexturation impacts followed a special order during ultrasound treatment leading at the end to the total detexturation of rosemary leaves [32].

\section{The effect of operational parameters on acidity value of the extracted oil}

The achieved results demonstrated that with enhancements in ultrasound power and irradiation time, the acidity value of the extracted oil may increase (Tables 1 and 2). Lipolytic enzymes under the thin grain shell are not able to hydrolyze fats in normal cells but in damaged cells these enzymes may start their activities and hydrolyze the oils and fats (substrate) and as a result may enhance the acidity of the extracted oils.

As shown in Fig. 1, application of ultrasound may lead to alterations in black cumin seed structure [10,33]. The achieved data in Table 3 also presented as well that minimum acidity value of oil is obtained when the ultrasound power and time were in their minimum values. Yamaguchi et al. [34] found out that once the polymerization grade leads to enhancements in superoxide scavenging, the photonic capability may also increase. Obviously, with enhancements in process temperature and ultrasound pretreatment time, the condition gets appropriate to eliminate antioxidant compounds and generate free radicals [35]. Acidity value might be used as a purity examination of the extracted oil and reveals that if oils had already started decomposition reactions.

\section{The refractive index of the extracted oil}

The refractive index (RI) is often used as a criterion for purity determination of the extracted oils. The RI of saturated fatty acids reveals a linear enhancement with escalating chain length. When RI is detected at a temperature above $40{ }^{\circ} \mathrm{C}$, the RI of unsaturated FA increases with a degree of unsaturation. In both cases, the RI value was detected equal to 1.470 , which is within the range reported in the literature for vegetable oils: olive oil (1.468-1.471), rapeseeds oil (1.465-1.469), sunflower seeds oil (1.467-1.469), and pumpkin seeds oil (1.466-1.474) as well as black cumin seeds oil (1.469-1.473) [36]. Tables 1 , 2 , and 3 presented as well that the use of different pretreatments have not affected significantly on refractive index $(P>0.05)$. Bakhshabadi et al. [10] studied the effects of pulsed electric fields and microwave pretreatments on some selected physicochemical properties of black cumin seeds oil and reported that these treatments have not affected significantly on refractive index of this oil.

\section{The effects of ultrasound power and time on the color parameters of the extracted oil}

Color is one of most important parameter demonstrating food products quality; this parameter has an important role in attracting customers. Further properties a

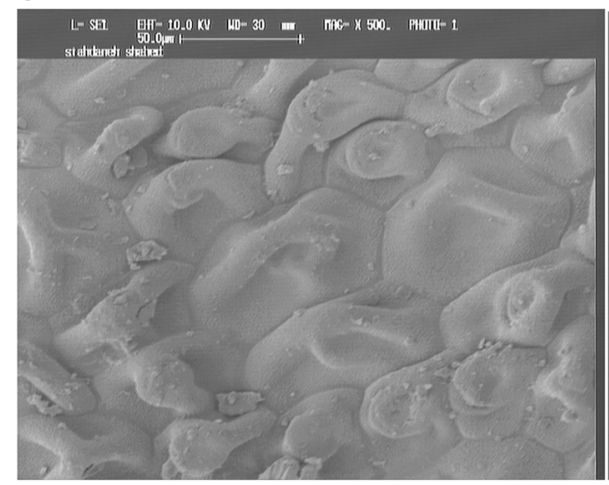

b

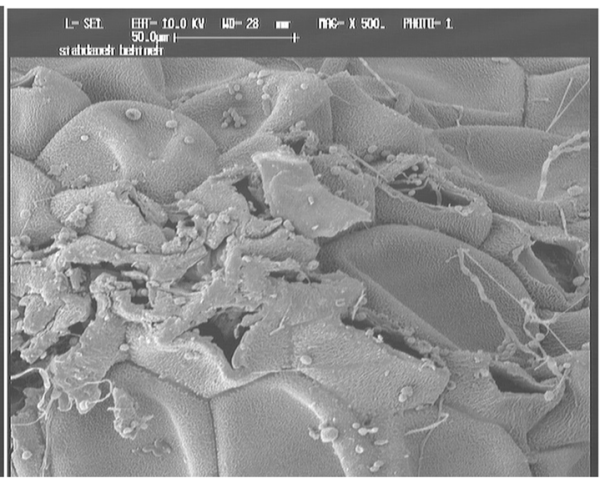

Fig. 1 SEM graphs of a standard sample (without ultrasound treatment) and $\mathbf{b}$ sample (with ultrasound treatment) 
Table 3 The interaction of ultrasound power and time on some properties of the selected samples

\begin{tabular}{llllllll}
\hline $\begin{array}{l}\text { Ultrasound } \\
\text { power }(\mathrm{W})\end{array}$ & $\begin{array}{l}\text { Ultrasound } \\
\text { time }(\mathrm{min})\end{array}$ & $\begin{array}{l}\text { Oil extraction } \\
\text { efficiency (\%) }\end{array}$ & $\begin{array}{l}\text { Acidity } \\
\text { (based on oleic acid\%) }\end{array}$ & $\begin{array}{l}\text { Refractive } \\
\text { index }\end{array}$ & $\begin{array}{l}\text { Color } \\
\text { index }\end{array}$ & $\begin{array}{l}\text { Peroxide } \\
\text { (meq oxygen per kg } \\
\text { of the extracted oil) }\end{array}$ \\
\hline 30 & 30 & $27.29 \pm 0.25 \mathrm{i}$ & $9.68 \pm 0.31 \mathrm{i}$ & $\begin{array}{l}\text { Total phenolic } \\
\text { content (ppm) }\end{array}$ \\
30 & 45 & $34.15 \pm 0.11 \mathrm{e}$ & $10.26 \pm 0.09 \mathrm{~g}$ & $1.471 \mathrm{a}$ & $109.8 \pm 0.53 \mathrm{i}$ & $8.00 \pm 0.08 \mathrm{i}$ & $71.2 \pm 1.31 \mathrm{i}$ \\
30 & 60 & $36.78 \pm 0.17 \mathrm{~d}$ & $11.57 \pm 0.27 \mathrm{c}$ & $1.471 \mathrm{a}$ & $117.2 \pm 1.11 \mathrm{f}$ & $9.50 \pm 0.06 \mathrm{~g}$ & $89.0 \pm 0.89 \mathrm{~g}$ \\
60 & 30 & $29.04 \pm 0.01 \mathrm{~h}$ & $10.12 \pm 0.16 \mathrm{~h}$ & $1.471 \mathrm{a}$ & $112.4 \pm 1.24 \mathrm{~g}$ & $10.50 \pm 0.21 \mathrm{f}$ & $92.4 \pm 0.33 \mathrm{f}$ \\
60 & 45 & $33.49 \pm 0.05 \mathrm{f}$ & $10.70 \pm 0.17 \mathrm{f}$ & $1.471 \mathrm{a}$ & $119.4 \pm 1.15 \mathrm{e}$ & $11.00 \pm 0.04 \mathrm{e}$ & $102.9 \pm 1.46 \mathrm{e}$ \\
60 & 60 & $37.22 \pm 0.10 \mathrm{c}$ & $11.83 \pm 0.01 \mathrm{~b}$ & $1.471 \mathrm{a}$ & $124.6 \pm 1.01 \mathrm{~d}$ & $11.50 \pm 0.11 \mathrm{~d}$ & $109.7 \pm 1.71 \mathrm{~d}$ \\
90 & 30 & $31.05 \pm 0.13 \mathrm{~g}$ & $10.83 \pm 0.01 \mathrm{e}$ & $1.471 \mathrm{a}$ & $131.2 \pm 0.13 \mathrm{c}$ & $11.70 \pm 0.09 \mathrm{c}$ & $115.9 \pm 0.19 \mathrm{c}$ \\
90 & 45 & $37.40 \pm 0.51 \mathrm{a}$ & $11.09 \pm 0.09 \mathrm{~d}$ & $1.471 \mathrm{a}$ & $132.3 \pm 0.09 \mathrm{~b}$ & $13.50 \pm 0.15 \mathrm{~b}$ & $117.0 \pm 0.31 \mathrm{~b}$ \\
90 & 60 & $39.93 \pm 0.19 \mathrm{a}$ & $12.86 \pm 0.17 \mathrm{a}$ & $1.471 \mathrm{a}$ & $136.5 \pm 0.47 \mathrm{a}$ & $15.00 \pm 0.33 \mathrm{a}$ & $121.1 \pm 0.42 \mathrm{a}$ \\
\hline
\end{tabular}

Data with different letters in each column expresses significant differences in the confidence level of $5 \%$

including smell, taste, and texture are parameters that are judged by customers after shopping of the products [37]. The achieved results of the current study demonstrated that with an enhancement in ultrasound power, color parameter of the extracted oil increased; the similar results were achieved when ultrasound irradiation time boosted (Tables 1 and 2). The cause of color enhancement of the extracted oils might be justified by the exhausting of pigments such as chlorophylls in the extracted oil and decomposition of phospholipids through ultrasound pretreatment processing. Jiménez et al. [38] reported that application of ultrasound might increase tocopherols, chlorophylls, and carotenoids contents in the extracted oils of olive oil.

\section{The influence of operative parameters on peroxide value of the extracted oil}

The achieved results presented that with enhancements in ultrasound power from 30 to $90 \mathrm{w}$, peroxide value of samples increased almost $12.14 \%$ and with enhancements in irradiation time from 30 to $60 \mathrm{~min}$, peroxide value might increase almost 54.55\% (Tables 1 and 2). The cause of enhancements in peroxide value might be attributed to oxidation reactions of fatty acids; this phenomenon may increase with boosting in the power and time of ultrasound pretreatment. Chemat et al. [39] found out that ultrasound waves might release free radicals as well as further volatile compounds and as a result increases peroxide value of the extracted oils.

Peroxides and hydroperoxides and the primary oxidation products decompose to form aldehydes, ketones, acids, alcohols, hydrocarbons, and other compounds. These substances are formed through thermal oxidation of oils and fats. The products of oil degradation as defined previously by International Union of Pure and Applied Chemistry [40] are polar materials. The polar fractions are composed from free fatty acids, monoglycerides, oxidized triglycerides, and oligomeric triglycerides.
Peroxide value is applied to detect the quantity of peroxide values in the extracted oils; these substances are important intermediate products of oxidative reactions since they decompose via transition metal irradiation and due to enhanced temperatures create free radicals [41]. These results were in solid agreement of the achieved results by [42].

\section{Total phenols}

Table 1 indicates that with enhancements in ultrasound power from 30 to $90 \mathrm{~W}$, the quantity of phenolic compounds increased from 93.21 to $106.6 \mathrm{ppm}$. With enhancements in ultrasound treatment time, the contact between solvent and solid materials increases leading to decomposition of cells' membrane and as a result mass transfer increases; it means enhancements in diffusion of phenolic compounds to solvent. On the other hand, ultrasound may lead to initiation in polymerization reaction in short time and as a result might increase the extracted phenolic contents [43, 44]. Other studies [22, 45] achieved similar outcomes. Corrales et al. [46], in a study, extracted the available anthocyanins in grape waste with the use of ultrasounds, high hydrostatic pressure, and pulsed electric field and studied the extraction efficiency. The obtained outcomes demonstrated that $1 \mathrm{~h}$ after the extraction process, total phenolic compounds of the treated samples with the use of novel pretreatment approaches was 5\% higher compared to control sample. Furthermore with the use of novel extraction approaches, antioxidant activity of the extracted infusions increased.

On the other hand, [47] demonstrated that the application of protracted ultrasound process in the extraction of plant-based phenolic compounds may lead to enhancements in extraction efficiency.

The degradation may result in a modification of macromolecular structures and a decrease of molecular weight leading to an improvement of the solubilization 
of polymers. However, the ultrasound effects have to be assessed on more complex structures since it is not obvious that these simplified models described for ultrasound impacts on single polymers would be valid for plant materials, which are composed of a large network of various polymers.

Table 3 demonstrates that the maximum amount of phenolic compounds is achieved once the power and time of ultrasound pretreatments were in the maximum degree.

\section{Conclusion}

The obtained results showed that with enhancements in ultrasound power, oil extraction efficiency, acidity and peroxide values, color parameter, and total phenolic contents increased. An increase in ultrasound irradiation time has shown the similar results. The application of ultrasound pretreatment has not presented significant effects on refractive index of the extracted oils. Regarding the achieved outcomes of the present research, it could be mentioned that the application of ultrasound pretreatments to treat the black cumin seeds before the extraction process with cold press approach may improve the quantitative and qualitative properties of the extracted oil. On the other hand, regarding the abovementioned advantages of ultrasound pretreatment and its applications and its impacts in the enhancements of extraction efficiency and phenolic compounds, it may be demonstrated that this approach may be used in medicinal and invaluable plant applications in industrial scales.

\section{Acknowledgements}

The authors would like to appreciate the Department of Chemistry, Gonbad Kavoos Branch, Islamic Azad University, Gonbad Kavoos, Iran, for the facilities provided during the present study.

\section{Availability of data and materials}

The data may be released for the reviewers and editor not for public due to the policy of the authors and University.

\section{Authors' contributions}

MM supervised the present research work and gave the required tips and scientific instructions. VF and HB did the experiments and obtained the data. All the achieved data were analyzed by all the authors. The article was prepared by $V F$ and $H B$. All authors read and approved the final manuscript.

Ethics approval and consent to participate

Not applicable.

\section{Consent for publication}

Not applicable.

\section{Competing interests}

The authors declare that they have no competing interests.

\section{Publisher's Note}

Springer Nature remains neutral with regard to jurisdictional claims in published maps and institutional affiliations.

\section{Author details}

'Department of Chemistry, Gonbad Kavoos Branch, Islamic Azad University, Gonbad Kavoos, Iran. ${ }^{2}$ Food Science lab, Meditbio, Faculty of Science and
Technology, University of Algarve, Faro, Portugal. ${ }^{3}$ Young Researchers and Elites club, Gorgan Branch, Islamic Azad University, Gorgan, Iran.

Received: 28 March 2018 Accepted: 12 July 2018

Published online: 10 August 2018

\section{References}

1. Kebriti M, Hoseini Mazhari SZ, Gerami A, Ghiassi B, Esfandyari C. Survey on the rate of losses and wastes in oil seeds processing plants in Tehran Province. J Food Technol Nutr. 2011:8(1):42-50.

2. Zomorrodi S, Shokrani R, Shahedi M, Dokhani S. Interesterification of mixtures of soybean oil with fully hydrogenated oil for production of shortenings. Iran J Agric Sci. 2003;34(3):587-95.

3. Ismail M, Al-Naqeep G, Chan KW. Nigella sativa thymoquinonerich fraction greatly improves plasma antioxidant capacity and expression of antioxidant genes in hypercholesterolemic rats. Free Radic Biol Med. 2010;2010(48):664-72.

4. Machmudah S, Shiramizu Y, Goto M, Sasaki M, Hirose T. Extraction of Nigella sativa L. using supercritical CO2: a study of antioxidant activity of the extract. Sep Sci Technol. 2005;40:1267-75.

5. Tiruppur Venkatachallam SK, Pattekhan H, Divakar S, Kadimi US. Chemical composition of Nigella sativa L. seed extracts obtained by supercritical carbon dioxide. J Food Sci Technol. 2010;47:598-605.

6. Oktay AS, Ethem GT, Omer FA. The protective effect of thymoquinone on ethanol-induced acute gastric damage in the rat. Nutr Res. 2005;25:673-80.

7. Halawani E. Antibacterial activity of thymoquinone and thymohydroquinone of Nigella sativa L. and their interaction with some antibiotics. Adv Biol Res. 2009;3(5-6):148-52.

8. Takruri HRH, Dameh MAF. Study of the nutritional value of black cumin seeds (Nigella sativa L). J Sci Food Agric. 1998;76:404-10.

9. Sarkis, J.R., Boussetta, N., Blouet, C., Tessaro, I.C., Ferreira Marczak, L.D. and Vorobiev, E. 2015. Effect of pulsed electric fields and high voltage electrical discharges on polyphenol and protein extraction from sesame cake. Inno. Innov Food Sci Emerg Technol 29: 170-177.

10. Bakhshabadi H, Mirzaei HO, Ghodsvali A, Jafari SM, Ziaiifar AM, Farzaneh V. The effect of microwave pretreatment on some physico-chemical properties and bioactivity of black cumin seeds' oil. Ind Crop Prod. 2017;97:1-9.

11. Chemat F, Rombaut N, Meullemiestre A, Turk M, Perino S, Sylvie FabianoTixier A, Abert-Vian M. Review of green food processing techniques. Preservation, transformation, and extraction. Innov Food Sci Emerg Technol. 2017:41:357-77.

12. Mason TJ. Power ultrasound in food processing - the way forward. In: Povey MJW, Mason TJ, editors. Ultrasound in food processing. London: Blackie Academic and Professional; 1998. p. 105-26.

13. Kadam SU, Tiwari BK, Álvarez C, O'Donnell CP. Ultrasound applications for the extraction, identification and delivery of food proteins and bioactive peptides. Trends Food Sci Technol. Technol. 2015;46:60-7.

14. Samaram S, Mirhosseini H, Tan CP, Ghazali HM, Bordbar S, Serjouie A. Optimisation of ultrasound-assisted extraction of oil from papaya seed by response surface methodology: oil recovery, radical scavenging antioxidant activity, and oxidation stability. Food Chem. 2015;172:7-17.

15. Arends BJ, Blindt RA, Janssen J, Patrick M. U.S. patent no. 6,630,185. Washington: U.S. Patent and Trademark Office; 2003.

16. Shirsath SR, Sonawane SH, Gogate PR. Intensification of extraction of natural products using ultrasonic irradiations-a review of current status. Chem Eng Process. 2012;53:10-23.

17. Lingyun W, Jianhua W, Xiaodong Z, Yalin Y, Chenggang C, Tianhua F, Fan Z. Studies on the extracting technical conditions of inulin from Jerusalem artichoke tubers. J Food Eng. 2007;79:1087-93.

18. Virot M, Tomao V, Le Bourvellec C, Renard CM, Chemat F. Towards the industrial production of antioxidants from food processing by-products with ultrasound-assisted extraction. Ultrason Sonochem. 2010;17(6):1066-74.

19. Jambrak AR, Mason TJ, Lelas V, Herceg Z, Herceg IL. Effect of ultrasound treatment on solubility and foaming properties of whey protein suspensions. J Food Eng. 2008;86:281-7.

20. Chemat F, huma ZE, Khmran khan M. Applications of ultrasound in food technology: processing, preservation and extraction. UltrasonicsSonochem. 2011;18(4):813-35.

21. Zhang ZS, Wang LJ, LI D, Jiao SS, Chen XD, Mao ZH. Ultrasound-assisted extraction of oil from flaxseed. Sep Purif Technol. 2008;62:192-8.

22. Lin JY, Zeng QX, AN Q, Zeng QZ, Jiang LX, Zhu ZW. Ultrasonic extraction of hempseed oil. J Food Process Eng. 2012;35:76-90. 
23. Goula AM. Ultrasound-assisted extraction of pomegranate seed oil-kinetic modeling. J Food Eng. 2013;117:492-8.

24. AOAC. Official methods of analysis of the association of official analytical chemists, vol. II. Arlington: Association of Official Analytical Chemists; 2008 .

25. AOCS. Official methods and recommended practices of the American oil chemists' society. Champaign: AOCS Press; 1993. p. 762.

26. Toma $\mathrm{M}$, et al. Investigation of the effects of ultrasound on vegetal tissues during solvent extraction. Ultrason Sonochem. 2001;8:137-42.

27. Vintoru M. An overview of the ultrasonically assisted extraction of bioactive principles from herbs. Ultrason Sonochem. 2001;8:303-13.

28. Carcel JA, Benedito J, Rossello C, Mulet A. Influence of ultrasound intensity on mass transfer in apple immersed in a sucrose solution. J Food Eng. 2007;78:472-9.

29. Giannelos PN, Sxizas S, Lois E, Zannikos F, Anastopoulos G. Physical, chemical and fuel related properties of tomato seed oil for evaluating its direct use in diesel engines. Ind Crop Prod. 2005;22:193-9.

30. Zhao S, Kwok KC, Liang H. Investigation on ultrasound assisted extraction of saikosaponins from Radix Bupleuri. Sep Purif Technol. 2007;55(3):307-12.

31. Abdullah S, Abdul Mudalip SK, Shaarani SM, Che PN. Ultrasonic extraction of oil from Monopterusalbus: effects of different ultrasonic power, solvent volume and sonication time. J Appl Sci. 2010;10:2713-6.

32. Khadhraoui B, Turk M, Fabiano-Tixier A, Petitcolas E, Robinet P, Imbert R, Maâtaoui ME, Chemat F. Histo-cytochemistry and scanning electron microscopy for studying spatial and temporal extraction of metabolites induced by ultrasound. Towards chain detexturation mechanism. Ultrason Sonochem. 2018;42:482.

33. Ghavami M, Gharachorloo M, Ezatpanah $\mathrm{H}$. Effect of frying on the oil quality properties used in the industry potato chips. J Agric Sci. 2003;9(1):1-15.

34. Yamaguchi F, Yoshimura Y, Nakazawa $H$, Ariga T. Free radical scavenging activity of grape seed extract and antioxidants by electron spin resonance spectrometry in an H2O2/NaOH/DMSO system. J Agric Food Chem. 1999;47:2544-8.

35. Zhang L, Shan Y, Tang K, Putheti R. Ultrasound-assisted extraction flavonoids from Lotus (NelumbonuficeraGaertn) leaf and evaluation of its anti-fatigue activity. Int J Phys Sci. 2009;4(8):418-22.

36. Haron H, Grace-Lynn C, Shahar S. Comparison of physicochemical analysis and antioxidant activities of Nigella sativa seeds and oils from Yemen, Iran and Malaysia (Perbandingan Analisis Fizikokimia dan Aktiviti Antioksidan dalam Biji dan Minyak Nigella sativa dari Yemen, Iran dan Malaysia). Sains Malays. 2014;43(4):535-42.

37. Khanipour, K and Shokrani, R. 2007. Detection of the optimized conditions of carotnoids extraction of tomato. Dood Science and Agricultural technics of Isfahan University of Technology 11(2), 23-37.

38. Jiménez A, Beltrán G, Uceda M. High-power ultrasound in olive paste pretreatment. Effect on process yield and virgin olive oil characteristics. Ultrason Sonochem. 2007;14(6):725-31.

39. Chemat F, Grondin I, Shum Cheong Sing A, Smadja J. Deterioration of edible oils during food processing by ultrasound. Ultrasonic Sonochem. 2004;11:13-5.

40. IUPAC. Standard methods for the analysis of oils, fats and derivatives (edited by Paquot C, Hautfenne A). Pure Appi Chem. 1987;51:2503-25.

41. Decker EA. Antioxidant mechanisms. In: Akoh CC, Min DB, editors. Food lipids, chemistry, nutrition, and biotechnology. New York: Marcel Dekker; 1998. p. 397-401.

42. Jalili F, Jafari SM, Emam-Djomeh Z, Malekjani N, Farzaneh V. Optimization of ultrasound-assisted extraction of oil from canola seeds with the use of response surface. Methodology. 2017:1-15.

43. Luque-Garcia JL, Luque de Castro MD. Ultrasound: a powerful tool for leaching. Trends Anal Chem. 2003;22(1):41-7.

44. Pinelo M, Fabbro PD, Manzocco L, Nunez MJ, andNicoli MC. Optimization of continuous extraction from Vitisvinifera by products. Food Chem. 2005;92:109-17.

45. Han L, Zhang HD, Luo SS, Luo K. Optimization of ultrasound-assisted extraction of total phenol from betel (Areca catechu L.) nut seed and evaluation of antioxidant activity in vitro. Afr J Biotechnol. 2011;10(46):9289-96.

46. Corrales M, Toepfl S, Butz P, Knorr D, Tauscher B. Extraction of anthocyanins from grape by-products assisted by ultrasonics, high hydrostatic pressure or pulsed electric fields: a comparison. J Innov Food Sci Emerg Technol. 2008;9:85-91.

47. M. Jacotet-Navarro, N. Rombaut, S. Deslis,A-S. Fabiano-Tixier, F-X. Pierre, A. Bily and F. Chemat. Towards a "dry" bio-refinery without solvents or 1 added water using microwaves and ultrasound for total valorization of fruits and vegetables by-products. 2016. Green Chemistry. 10.

Ready to submit your research? Choose BMC and benefit from:

- fast, convenient online submission

- thorough peer review by experienced researchers in your field

- rapid publication on acceptance

- support for research data, including large and complex data types

- gold Open Access which fosters wider collaboration and increased citations

- maximum visibility for your research: over $100 \mathrm{M}$ website views per year

At BMC, research is always in progress.

Learn more biomedcentral.com/submissions 